\title{
An Analysis to Peng Zhen's Legal Education Thought ${ }^{1}$
}

\author{
Jian-Fa HU² \\ School of Humanities and Economics Law, Northwestern Polytechnical University, Xi'an, China \\ 710129 \\ hjfa2005@nwpu.edu.cn
}

Key words: Peng Zhen, legal system, law-abiding, education, popularization of law, supervision

\begin{abstract}
Peng Zhen's thought of democracy and legal system is extremely rich, but the relevant research is still not enough. On the basis of Peng's legislative thoughts and law enforcement thoughts, this article discusses his theory on the propaganda of socialist legal education around the law-abiding thoughts and legal supervision to guide the further development of our legal education practice.

As the main founder of the socialist legal system, Peng Zhen has long presided over the work of the NPC Standing Committee, in the long-term work practice, accumulated valuable thought wealth, especially his legal education, current research On Three Problems of Peng Zhen's Legal Education.
\end{abstract}

\section{How to Understand the Socialist Legal Education}

The essence of socialist legal education is "the law to the people", its purpose is to make the enactment of the law can be effectively implemented.

After the Third Plenary Session of the 11th CPC Central Committee, Peng Zhen presided over the legislative work of the National People's Congress. China began large-scale legislative activities, but at home and abroad doubts the new China can really implement the rule of law, in other words, some people do not believe the law we developed is enforceable. In this regard, Peng Zhen pointed out that some people say that although the rule of law is very good, but it cannot be implemented and I think the central leadership, the law to the 900 million people......how the law cannot be implemented? The key is to let one billion people have the national destiny of their own people...The billions of people have come to oversee the implementation of the law, so that we believe, we will be able to implement as long as the law is enacted correctly.

In Peng's view, the law must be effectively implemented depends on two points: First, the law should be developed correctly, the second is to the law to the people. The so-called "right to be enacted by the law" has both physical and formal conditions, that is, the law should represent the most fundamental interests of the overwhelming majority of the people and enact laws enacted through democratic legislation to maximize the real needs of the people. The nature of our country determines the socialist legal system represents the fundamental interests of the broad masses of the people, as Peng Zhen said, China's law is the working class led by the people of the whole country, is the majority of the will and interests of the concentrated expression, The law of the state protects the interests of the people and represents the interests of the 900 million people. And the legislative democracy can be guaranteed through the party's tradition of upholding the mass line. When it comes to hand over the law to the people, this is essentially the propaganda of legal education, which is to let the "law" from the masses come back to the masses. This again demonstrates our Party's consistent adherence to the mass line method of work. To carry out socialist legal education is to make people know the law through various means, thus abiding by the law and consciously safeguarding the implementation of the law. State organs and individuals to act in accordance with the law, to expose, prosecute and struggle to any illegal acts, you can effectively ensure the

\footnotetext{
${ }^{1}$ This paper is the result of the research on Peng Zhen's Legal Education Thought of the northwestern university of technology.

2 Jianfa $\mathrm{Hu}$ (1977-), male, han nationality, wuhan native of hubei province, master of law, southwest university of political science and law, is a teacher of humanities and law school of the northwestern university of technology.
} 
implementation of the law.

Clearly, the reality of our country has been fully in line with the requirements of the above two points, therefore, enacted law is fully able to be effectively implemented, and in fact, these laws in China not only been well implemented, but also greatly adapt and promote Especially the normal and healthy development of various construction activities during the period of reform and opening up.

\section{The Reason for Choose Socialist Legal Education}

Socialist legal system education is an urgent task of socialist legal construction. The education of socialist legal system is determined by the social background and practical needs at that time.

\section{The Social Background}

Since "Cultural Revolution" ended, people thought the field is chaotic. First, the feudal privilege of cadres in serious thinking, the second is the masses of "legal nihilism" prevails," law lessness" social atmosphere has not been fundamentally reversed. Under this circumstance, Peng Zhen pointed out that all the people are equal before the law, which is the slogan of all our people, all the members of the Communist Party and the revolutionary cadres, and is an ideological weapon to oppose the privilege of anyone. In front of the law, Party members and revolutionary cadres are only by taking the lead, exemplary compliance with the obligations of the law, there must be no privilege not to abide by the law. Continuing to carry out the socialist legal system education in general is the first publicity and education of the Constitution, so that every citizen, especially every cadre, firmly establish the concept of the rule by law, especially the constitutional concept, and gradually make our constitution and law household, Everyone develop to comply with the Constitution and the law, according to the concept and habits. Which at the time produced a strong shock.

\section{The Need for Legal Education}

First of all, it is the need to educate party members and cadres to abandon the idea of privilege. As early as 1948, Peng Zhen put forward should be disciplined, especianly the cadres and party members to become the model. Here, he further stressed that the cadres and members of the Communist Party must lead by example in compliance with the Constitution and the law, to become law-abiding model, and the unity of the masses for the implementation of the Constitution and various laws and struggle. In 1980, Peng Zhen put forward that in the feudal era the prince and the common people commit crimes with crime, in fact, which is just empty words, while he speaks there said that the prince breaks the law, but not the king, so that the king cannot abide by the law.

Secondly, it is the need to educate the masses of the people to obey the law. "Comrade Mao Zedong in his article that is "where the right thought of man is coming from" said that The correct idea of representing the advanced class, once mastered by the masses, becomes the material force for transforming society and transforming the world. 'Our Constitution, which embodies the will and the interests of the greatest majority of the people, is not only the correct idea of representing the advanced class, but also a powerful weapon of the people's mastership, and it is further popularized by the masses, Become more powerful material forces. It can prevent the "Cultural Revolution" or similar disaster recurrence, safeguarding the country's long-term stability. Peng believes that as long as the broad masses of the people develop the concept and practice of legality, learn to use legal weapons to safeguard the common cause of socialism, safeguard the legitimate rights and interests of citizens, and with the violation of the Constitution, the law and undermine socialism Legal system of action to fight, we can become a great material force.

Finally, it is the need to guide the broad masses of people in supervising the implementation of the law. Peng Zhen believes that the masses of the people are the masters of state and national laws, and the masses of the people to be a good master, we must master the legal weapons, we must mobilize the people to carry out supervision. He said that the legal supervision, in addition to the National People's Congress, the State Council, the Supreme People's Court, the Supreme People's 
Procuratorate need to strengthen this work, a very important aspect is the mass supervision. A socialist country, the socialist democracy, Law, cannot act in strict accordance with the law, cannot supervise the implementation of the law, how cannot. In his view, everyone can carry out supervision, the only way, the people of the country to manage the country, to control their own destiny, the power of the people themselves. Thus, the combination of static and dynamic legal supervision mechanism in order to establish the authority of the law to effectively protect the implementation of the law to ensure the enjoyment and exercise of civil rights, to achieve long-term stability of the country.

\section{How to Carry Out Socialist Legal Education}

How to carry out socialist legal education to improve the concept of the people's legal system? To answer this question, we need to proceed from our reality. This is the embodiment of Peng Zhen's application of the basic idea of "seeking truth from facts" - the Marxist stand, viewpoint and method of solving the practical problems. Only by grasping the actual situation in order to effectively improve the legal education and publicity to ensure that the law must be strictly enforced, the construction of a socialist country under the rule of law.

\section{The Law of Education}

\section{The Emergence of the Concept of Law Education.}

Peng Zhen's popularization of the concept of education in the early liberation. In September 1953, Peng really fully affirmed the "Marriage Law" large-scale publicity campaign, at the same time, he put forward the national staff and the whole nation's law-abiding education should be strengthened .Regrettably, this proposal was not implemented at that time.

\section{The Development of Education Law Popularization.}

The formation of Peng Zhen's popularizing educational thoughts began after the reform and opening up, and developed continuously in the subsequent political and legal work. In June 1979, Peng Zhen, referring to the revision of the draft of the Criminal Law, pointed out that propaganda and education must be carried out extensively among cadres and the masses, and the public, procuratorial and judicial personnel should be well organized to study. At that time, the background was that after the Third Plenary Session of the 11th CPC Central Committee, the reform and opening-up policy was implemented and the focus of the Party and the state shifted to economic construction, which raised high demands on the legal concept of the broad masses of the people. But at that time, as Peng Zhen said that the ubiquitous problem is that the concept of the rule of law is not strong enough, there must be a process, there is a customary problem, and for thousands of years nobody speak the rule of law, and now everyone to develop the habit of doing things according to law, which is not easy. With the development of the situation, Peng Zhen once again put forward the legal system should be universal publicity and education. This is the first time for Peng Zhen to say that all-people legal education should be carried out in the new era.

When explaining the seven draft laws, Peng put forward that in order to give the law to the 900 million people and so that they can master it, it is necessary to carry out publicity and education extensively among the cadres and the masses before the implementation. To this end, he suggested that these seven laws after the announcement, from January the following year the official implementation. During this period, it is necessary to carry out the study and propaganda on socialist democracy and the rule of law among the people throughout the country, so that these seven laws can become household. He also said that in the future also need to conduct regular publicity and education on democracy and the rule of law, to strengthen the legal concept of the cadres and the masses in provinces, autonomous regions and municipalities, so that we learn to use legal weapons according to their own situation. In a unified deployment, in an orderly manner. This shows that Peng Zhen at this time has begun to produce the idea of law which is similar to initial "five" law popularization of the national long-term large-scale legal education. 
Later, Peng also repeatedly stressed the importance of socialist legal education at different times and on different occasions. In his view, this is an important task of building a socialist legal system without delay.

In 1983, Peng Zhen, referring to the implementation of the Constitution, pointed out: "First of all, we need to adopt various forms and closely integrate with reality, and continue to carry out the socialist legal system in general. First, the propaganda and education of the constitution so that every citizen, every cadre, firmly establish the concept of the rule of law, especially the concept of the Constitution, and gradually make our constitution and the law well-known, everyone to develop to comply with the Constitution and the law, according to the concept and habits.

\section{The Practice of Law Education}

Peng Zhen in view, the legal education and publicity is an urgent task, but also a major event for the country and the people. In 1985, under the auspices of Peng Zhen, the Standing Committee of the Sixth National People's Congress adopted the "Resolution on the Basic Popularization of Legal Knowledge among Citizens", which stipulated that from 1986 onwards, it would take five years or so to plan, To popularize legal education among all the citizens who have the ability to accept it, and to gradually institutionalize and regularize the popularization of law education. Thus began in the hundreds of millions of people in the popular legal knowledge, strengthen the legal education of the grand project.

By 1990, China completed the "First Five-Year" plan for the popularization of law, with a total of more than 700 million people participating in the popularization of law. Among them, 480,000 were county-level cadres, 9.5 million were cadres, and some 150 million were middle and primary school students Accepted the legal education, the country's major, middle and primary schools as well as all levels of Party schools, cadre schools have opened most of the legal education courses.

So far, the "fifth five-year plan" has been successfully concluded, "Sixth Five-Year" law popularization has been kicked off, in the popular law enforcement activities have become an important basis for the rule of law.

With the deepening of the popularization of law, the cadres have strengthened the awareness of law and promoted the process of gradual legalization of daily work. The broad masses of the people have gradually learned the importance of law-abiding and can use law to protect the legitimate rights and interests of individuals. Law and the broad masses of the people together, is forming an increasingly powerful material forces, and promote our country toward a democratic, prosperous and strong socialist country ruled by law into the fast forward.

Under the personal care of Peng Zhen, the legal education of our country has been gradually institutionalized, regularized and the popularization of law has made remarkable achievements, which becomes an indispensable part of the socialist legal construction. Of course, while affirming our achievements, we should also clearly realize that we still have a long way to go before we can comprehensively improve the legal quality of the people of the whole country to meet the basic needs of socialist modernization. As Peng Zhen said, the education of legal popularization is that a long and arduous task in developing socialist democracy and perfecting the socialist legal system, and we must always pay close attention to it and persistently carry it out in the whole primary stage of socialism.

Under the new historical conditions, we should strengthen the publicity and education of the legal system, strengthen the legal consciousness and the legal concept of the whole society, and provide a strong ideological motive for the further implementation of the basic strategy of "ruling the country according to law and building a socialist country ruled by law".

\section{References}

[1]Zhu Liyu. Peng Zhen's thought for the democracy and legal system [M].Renmin University of China Press, 1999.

[2]Peng Zhen.On thev political and legal work of the new China [M].Central Literature Publishing 
House, 1992.

[3]Peng Zhen.On the new era of socialist democracy and the legal system [M].the Central Literature Publishing House, 1989.

[4]Peng Zhen.Peng Zhen's wen election [M].People's Publishing House, 1991. 